\title{
PENGARUH TERAPI TAMBAHAN ASAM FOLAT DAN KOBALAMIN TERHADAP GEJALA SKIZOFRENIA KRONIK
}

\author{
Betty Hidayati, Aris Sudiyanto, Moh. Fanani \\ Pascasarjana Kedokteran Keluarga Universitas Sebelas Maret
}

\begin{abstract}
Folic Acid, Cobalamin, Symptoms, Schizophrenia. Schizophrenic patients have low levels of folic acid and cobalamin. Deficiency of folic acid and cobalamin can cause neurological and psychiatric disorders. Supplementation of folic acid and cobalamin may provide therapeutic benefits through different mechanisms of current treatment regimens. To assess the effectiveness of additional therapies of folic acid and cobalamin in improving the negative symptoms and length of stay of chronic schizophrenic patients. This study was an experimental study with randomized controlled trial group, pre-post test design. The intervention group had significant PANSS score improvementin positive symptoms $(p=0,01)$, negative symptoms $(p=$ $0,004)$, general psychopathologies $(p=0,01)$ and PANSS total score $(p=0,014)$ subscales. ONE-WAY ANAVA statistic analysis result shows significant reduction in all four subscales $(p=0,000)$. Adding folic acid and vitamin $B_{12}$ as adjuvant therapy with standard antipsychotic medication effective in reducing chronic schizophrenia symptoms.
\end{abstract}

Keywords: Folic Acid, Cobalamin, Symptoms, Schizophrenia

Abstrak: Folic Acid, Cobalamin, Symptoms, Schizophrenia. Pasien skizofrenia mempunyai kadar asam folat dan kobalamin yang rendah. Defisiensi asam folat maupun kobalamin dapat menyebabkan gangguan neurologis dan psikiatris. Suplementasi asam folat dan kobalamin dapat memberikan manfaat terapeutik melalui mekanisme yang berbeda dari rejimen pengobatan saat ini. Tujuan penelitian ini adalah untuk mengetahui pengaruh terapi tambahan asam folat dan kobalamin terhadap gejala pasien skizofrenia kronis. Studi ini merupakan penelitian eksperimental dengan rancangan randomized controlled trial group, pre-post test design. Pada kelompok intervensi didapatkan perbaikan skor PANSS yang signifikan pada subskala gejala positif $(\mathrm{p}=0,01)$, gejala negatif $(\mathrm{p}=0,004)$, psikopatologi umum $(\mathrm{p}=0,01)$ dan PANSS total $(\mathrm{p}=0,014)$. Hasil analisis $O N E-W A Y$ ANAVA didapatkan adanya penurunan yang signifikan $(\mathrm{p}=0,000)$ pada keempat subskala tersebut. Penambahan asam folat dan kobalamin sebagai terapi tambahan pada terapi antipsikotik standar efektif dalam memperbaiki gejala skizofrenia kronis.

Kata Kunci: Folic Acid, Cobalamin, Symptoms, Schizophrenia

\section{PENDAHULUAN}

Menurut penelitian di berbagai negara, prevalensinya pada populasi umum berkisar $1 \%$ (Howes and Murray,
2014). Di Indonesia angka kejadian skizofrenia mencapai 1,7 per 1000 penduduk Indonesia atau sekitar 400.000 orang (Depkes, 2014). 
Sebuah studi oleh Silver (2000) pada 644 pasien psikotik yang dirawat melaporkan bahwa $78.3 \%$ pasien penderita skizofrenia mengalami defisiensi vitamin $B_{12}$. Beberapa studi dengan jelas menunjukkan kontribusi asam folat, vitamin $\mathrm{B}_{12}$ dan homosistein pada perubahan metabolisme karbon tunggal dan perannya dalam psikopatofisologi skizofrenia. Serum dan RBC (Red Blood Cell) folat pada pasien penderita skizofrenia secara signifikan lebih rendah daripada kelompok kontrol (Ahmad, 2011).

Wang et.al. tahun 2016 melakukan penelitian metaanalasis mengenai hubungan antara serum folat dan risiko skizofrenia. Penelitian menggunakan data PubMed, Embase, dan Web of Science. Hasil metanalisis menunjukkan adanya hubungan antara serum folat dan risiko skizofrenia yang signifikan dengan model penelitian random $\left(\mathrm{p}=0.001, I^{2}=90.3\right)$. Penelitian menunjukkan bahwa penurunan serum asam folat berhubungan dengan faktor risiko skizofrenia $(p=0.001)$

Folat dan vitamin $\mathrm{B}_{12}$ dibutuhkan pada metilasi homosistein menjadi metionin maupun sintesis SAM $(S$ adenosylmethionine). terlibat $S$ adenosylmethionine terlibat dalam berbagai reaksi metilasi melibatkan protein, fosfolipid, DNA (deoxyribonucleic acid), dan metabolisme neurotransmiter. Baik defisiensi asam folat maupun vitamin $B_{12}$ dapat menyebabkan gangguan neurologis dan psikiatris. Teori menyatakan bahwa cacat dalam proses metilasi merupakan dasar biokimia utama neuropsychiatry akibat defisiensi vitamin ini. Defisiensi folat secara spesifik mempengaruhi metabolisme pusat monoamin dan memperburuk gangguan psikiatri (García-
Miss et.al., 2009). Tingginya kadar homosistein dalam darah telah dikaitkan dengan beberapa gangguan psikiatri dan neurodegeneratif termasuk depresi, skizofrenia, penyakit Alzheimer, dan penyakit Parkinson (Bottiglieri, 2009) yang terkait dengan defisiensi folat dan vitamin $\mathrm{B}_{12}$ (García-Miss et.al, 2009).

Menurut penelitian yang dilakukan Patel et.al. (2014) terhadap 7678 pasien skizofrenia didapatkan 4269 patients $(55,7 \%)$ mengalami 1 gejala negatif. Menurut penelitian yang dilakukan Patel et.al. (2015) terhadap 1609 pasien skizofrenia yang menjalani rawat inap, menyimpulkan bahwa gejala negatif berhubungan dengan durasi rawat inap yang lebih panjang. Menurut penelitian Oshima et.al. (2003) terdapat hubungan yang signifikan antara gejala negatif dengan lama rawat inap pasien skizofrenia. Akan sampai saat ini belum ada terapi yang efektif untuk mengatasi gejala negatif (Miyamoto et.al., 2005).

Teori saat ini menyatakan bahwa proses biokimia metilasi dasar neuropsikiatri adalah defisiensi folat dan kobalamin. Hal ini telah dibuktikan dari beberapa studi klinis dan eksperimental. Reaksi penting yang menghubungkan folat dan vitamin $B_{12}$ pada proses metilasi dikatalisis oleh enzim metionin sintetase. Reaksi ini terbentuk dari gugus metil 5-methyltetrahydrofolate (MTHF) yang ditransfer ke homosistein untuk membentuk metionin dan tetrahydrofolate (gambar 1). Sintesis de novo metionin memerlukan vitamin $\mathrm{B}_{12}$ yang terlibat langsung pada transfer metil kelompok sintesis S-adenosylmethionine (SAM), satu-satunya donor metil dalam berbagai reaksi metilasi melibatkan protein, fosfolipid dan amina biogenik. Produk dari semua reaksi metilasi adalah $S$ - 
adenosylhomocysteine (SAH), yang dengan cepat dimetabolisme menjadi homosistein (Sarah, 2011).

Homosistein dihasilkan sepenuhnya dari siklus metilasi. Defisiensi folat dan vitamin $\mathrm{B}_{12}$ menyebabkan efek pada sintesis metionin. Penelitian Stabler menunjukkan bahwa plasma total homosistein meningkat signifikan pada keadaan defisinesi folat dan vitamin $\mathrm{B}_{12}$ sebagai akibat dari penurunan aktivitas metionin sintetase dan kegagalan pembentukan methylate homosistein secara efektif (Sarah, 2011).

\section{METODE PENELITIAN}

Penelitian ini merupakan

penelitian eksperimental dengan rancangan randomized controlled trial, pre-post test design. Populasi target dari penelitian ini adalah pasien skizofrenia kronik yang menjalani rawat inap di RSJD Surakarta. Sampel pada penelitian ini adalah 30 pasien skizofrenia kronik untuk kelompok intervensi dan 30 pasien skizofrenia kronik pada kelompok kontrol. Gejala skizofrenia dinilai dengan instrumen PANSS. Perhitungan jumlah sampel berdasarkan rumus besar sampel. Teknik sampling menggunakan simple random sampling. kriteria inklusi: Pasien skizofrenia yang telah mengalami gangguan minimal selama 2 tahun. Pasien mendapat pengobatan antipsikotik kombinasi risperidon - chlorpromazine. Pasien yang menjalani rawat inap di RSJD Surakarta, usia 21-50 tahun. Keluarga pasien bersedia mengikuti penelitian dan menandatangani surat persetujuan. Kriteria eksklusi: Keluarga tidak bersedia mengikuti penelitian. Analisis data menggunakan uji $\mathrm{T}$ tidak berpasangan untuk mengetahui keefektivan intervensi.

\section{HASIL PENELITIAN}

\section{Tabel 1}

Karakteristik Demografi Subyek Studi

\begin{tabular}{llll}
\hline Variabel & $\begin{array}{l}\text { Kelompok } \\
\text { Intervensi }\end{array}$ & Kontrol & Nilai p \\
\hline Jenis kelamin : & & & 0,07 \\
- Laki-laki & $19 / 30$ & $11 / 30$ & \\
- Perempuan & $(63,33 \%)$ & $(36,67 \%)$ & \\
& $11 / 30$ & $19 / 30$ & \\
& $(36,67 \%)$ & $(63,33 \%)$ & \\
Umur (mean) & $36,77 \pm 9,06$ & $34,53 \quad \pm$ & 0,262 \\
& & 5,86 & \\
Pendidikan : & $3 / 30(10 \%)$ & $8 / 30$ & 0,425 \\
- Tidak & $7 / 30$ & $(26,67 \%)$ & \\
$\quad$ sekolah & $(23,33 \%)$ & $8 / 30$ & \\
- SD & $8 / 30$ & $(26,67 \%)$ & \\
- SMP & $(26.67 \%)$ & $7 / 30$ & \\
- SMA/SMK & $11 / 30$ & $(23,33 \%)$ & \\
- PT & $(36,67 \%)$ & $7 / 30$ & \\
& $1 / 30(3,33 \%)$ & $(23,33 \%)$ & \\
Pekerjaan : & & $0 / 30(0 \%)$ & \\
- Bekerja & $16 / 30$ & $8 / 30$ & 0,065 \\
- Tidak bekerja & $(53,33 \%)$ & $(26,67 \%)$ & \\
& $14 / 30$ & $22 / 30$ & \\
Status & $(46,67 \%)$ & $(73,33 \%)$ & \\
permenikahan : & $9 / 30(30 \%)$ & $5 / 30$ & 0,360 \\
- Menikah & $21 / 30(70 \%)$ & $(16,67 \%)$ & \\
- Tidak & & $25 / 30$ & \\
menikah & & $(83,33 \%)$ & \\
\hline
\end{tabular}

Karakteristik demografi subjek studi didapatkan pada kelompok intervensi subjek dengan jenis kelamin laki-laki $(63,33 \%)$ lebih banyak dari pada perempuan $(36,67 \%)$. Subjek kelompok kontrol lebih banyak perempuan $(63,33 \%)$ dari pada laki-laki $(36,67 \%)$, sedangkan untuk total laki-laki dan perempuan sama banyak (masing-masing 50\%). Untuk variabel umur, umur rata-rata kelompok intervensi $(36,77 \pm 9,06)$ sedikit lebih tua daripada umur rata-rata kelompok kontrol. Pada variabel pendidikan, didapatkan pada kelompok intervensi lebih banyak lulusan SMA/SMK (36,67\%), sedangkan untuk lulusan Perguruan Tinggi $(3,33 \%)$, SMP (26.67\%), SD (23,33\%) dan subjek 
yang tidak sekolah (10\%). Untuk kelompok kontrol sama banyak antara yang tidak sekolah dengan lulusan SD (masing-masing 26,67\%), SMP $(23,33 \%)$, dan SMA $(23,33 \%)$.

Pada variabel pekerjaan, didapatkan pada kelompok intervensi lebih banyak yang bekerja $(53,33 \%)$ daripada yang tidak bekerja $(46,67 \%)$. Pada kelompok kontrol lebih banyak yang tidak bekerja $(73,33 \%)$ daripada yang bekerja $(26,67 \%)$. Untuk total lebih banyak yang tidak bekerja (60\%). Pada variabel status permenikahan, didapatkan pada kelompok intervensi lebih banyak yang tidak menikah $(70 \%)$ daripada menikah $(30 \%)$, untuk kelompok kontrol juga lebih banyak yang tidak menikah $(83,33 \%)$ daripada yang menikah (16,67\%), sedangkan untuk total subjek juga lebih banyak yang tidak menikah (76.67\%).

Berdasarkan tabel 1 dilakukan uji komparatif terhadap karakteristik demografik kedua kelompok. Dengan uji tersebut didapatkan tidak ada perbedaan yang bermakna antara kelompok intervensi dan kelompok kontrol pada jenis kelamin $(p=0,07)$, umur $(p=0,262)$, pekerjaan $(\mathrm{p}=0,065)$, status permenikahan $(\mathrm{p}=0,360)$ dan tingkat pendidikan $(\mathrm{p}=0,425)$. Uji ini dilakukan agar data yang didapat memenuhi syarat untuk dilakukan uji statistik berikutnya.
Tabel 2

Nilai Rata-Rata (mean) Skor PANNS Pretest Pada Kelompok Intervensi Dan Kontrol

\begin{tabular}{|c|c|c|c|}
\hline \multirow[t]{2}{*}{ Variabel } & \multicolumn{2}{|c|}{ Kelompok } & \multirow{2}{*}{$\begin{array}{l}\text { Nilai } \\
\mathrm{p}\end{array}$} \\
\hline & $\begin{array}{l}\text { Intervensi } \\
(\mathrm{n}=30)\end{array}$ & $\begin{array}{l}\text { Kontrol } \\
(\mathrm{n}=30)\end{array}$ & \\
\hline $\begin{array}{l}\text { PANNS } \\
\text { gejala positif }\end{array}$ & $22,5 \pm 5,87$ & $24,89 \pm 6,61$ & 0,228 \\
\hline $\begin{array}{l}\text { PANNS } \\
\text { gejala negatif }\end{array}$ & $\begin{array}{l}22,47 \quad \pm \\
9,12\end{array}$ & $25,33 \pm 8,11$ & 0,203 \\
\hline $\begin{array}{l}\text { PANNS } \\
\text { psikopatologi } \\
\text { umum }\end{array}$ & $\begin{array}{l}40,83 \\
11,31\end{array}$ & $43 \pm 13,17$ & 0,497 \\
\hline $\begin{array}{l}\text { PANNS } \\
\text { risiko agresi }\end{array}$ & $7,83 \pm 2,28$ & $8,07 \pm 2,82$ & 0,970 \\
\hline PANNS total & $\begin{array}{l}93,13 \quad \pm \\
21,95\end{array}$ & $101,5 \pm 23,22$ & 0,157 \\
\hline $\begin{array}{l}\text { Pa } \\
\text { dilakukan } \\
\text { dapat dil } \\
\text { bermakna } \\
\text { pretest b } \\
\text { gejala ne } \\
\text { umum } \\
\text { maupun sl }\end{array}$ & $\begin{array}{l}\text { skor } \\
\text { dji beda, } \\
\text { lat adany } \\
\text { nilai rata- } \\
\text { k gejala } \\
\text { atif }(\mathrm{p}=0 \text {, } \\
=0,497) \text {, } \\
\text { or total }(\mathrm{p}=\end{array}$ & $\begin{array}{l}\text { PANSS } \\
\text { ari dua ke } \\
\text { perbedaan } \\
\text { ata skor } \\
\text { positif ( }= \\
\text { 03), psikor } \\
\text { agresi (p= } \\
\text { 157). }\end{array}$ & $\begin{array}{r}\text { pretest } \\
\text { ompok } \\
\text { tidak } \\
\text { ANNS } \\
0,228), \\
\text { atologi } \\
0,970),\end{array}$ \\
\hline
\end{tabular}

Tabel 3

Nilai Rata-Rata (Mean) Skor PANNS Postest Pada Kelompok Intervensi Dan Kontrol

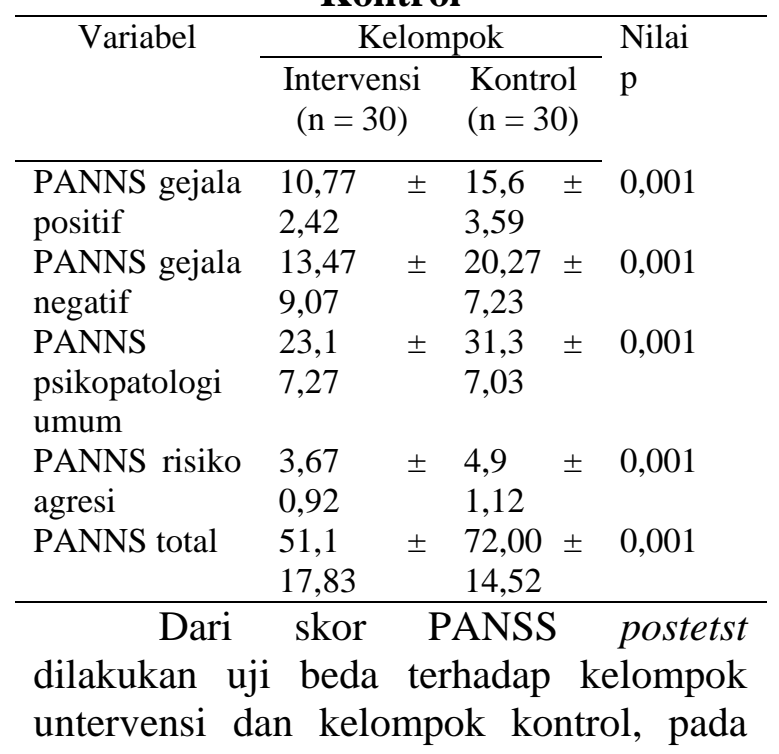


dua kelompok didapatkan perbedaan bermakna nilai rata-rata skor PANNS posttest baik gejala positif $(\mathrm{p}=0,001)$, gejala negatif $(\mathrm{p}=0,001)$, psikopatologi umum $(\mathrm{p}=0,001)$, agresi $\quad(\mathrm{p}=0,001)$, maupun skor total $(\mathrm{p}=0,001)$.

\section{Tabel 4}

Nilai Rata-Rata (mean) Selisih Skor PANNS Pretest-Postest Pada Kelompok Intervensi Dan Kontrol

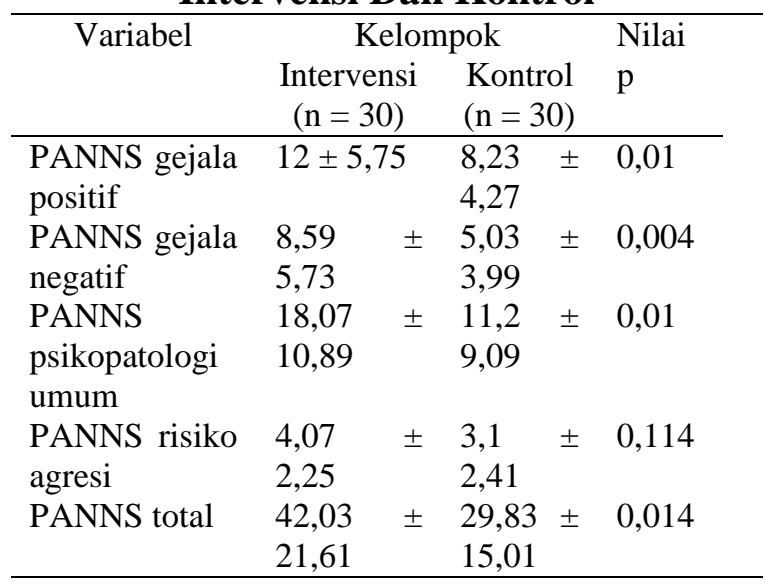

Pada tabel 4 didapatkan nilai ratarata (mean) selisih skor PANNS pretestpostest pada kelompok intervensi lebih besar daripada kelompok kontrol pada semua variabel. Analisa statistik menggunakan uji t tidak berpasangan karena sebaran data semua variabel tersebar normal. Didapatkan perbedaan nilai rata-rata (mean) selisih skor PANNS pretest-postest antara kelompok intervensi dan kelompok kontrol yang signifikan terdapat pada skala gejala positif $(p=0,01)$, skala gejala negatif $(\mathrm{p}=0,004)$, skala psikopatologi umum $(\mathrm{p}=0,001)$ dan skor PANNS total $(\mathrm{p}=0,014)$. Sedangkan pada skala risiko agresi, perbedaaan nilai ratarata selisih skornya tidak signifikan $(\mathrm{p}=0,114)$.

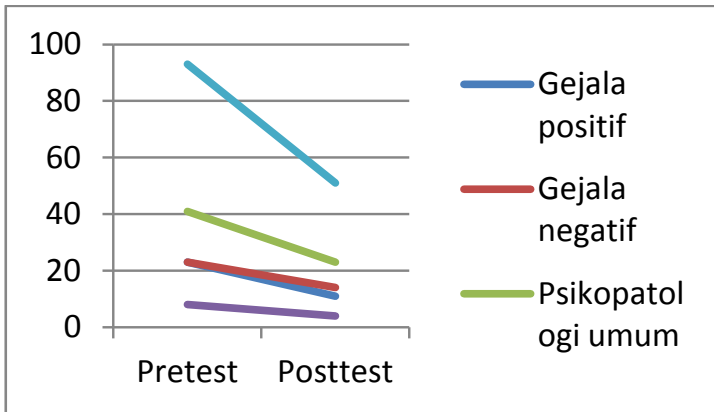

Grafik 1 Penurunan nilai rata-rata skor PANNS total dan subskala antara pretest dan posttest pada kelompok intervensi.

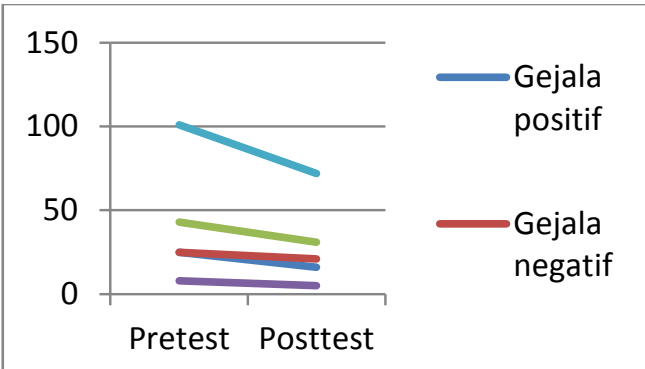

Grafik 2 Penurunan nilai rata-rata skor PANNS total dan subskala antara pretest dan posttest pada kelompok kontrol.

Selanjutnya dilakukan uji OneWay ANOVA nilai rata-rata selisih skor PANSS postest subsakala gejala positif, negatif, psikopatologi umum, dan PANSS total kelompok intervensi. Dari hasil uji statistik didapatkan selisih skor PANSS yang bermakna pada keempat subskala (gejala positif, negatif, psikopatologi umum, dan PANSS total)dengan nilai $\mathrm{p}=0,000$.

\section{PEMBAHASAN}

Pada studi ini jenis kelamin laki-laki didapatkan sama banyak dengan perempuan, masing-masing $50 \%$. Skizofrenia adalah sama-sama prevalensinya antara laki-laki dan wanita. Tetapi, dua jenis kelamin tersebut menunjukkan perbedaan dalam onset dan perjalanan penyakit. Laki-laki mempunyai 
onset skizofrenia yang lebih awal daripada wanita. Beberapa penelitian telah menyatakan bahwa laki-laki adalah lebih mungkin daripada wanita untuk terganggu oleh gejala negatif dan bahwa wanita lebih mungkin memiliki fungsi sosial yang lebih baik daripada laki-laki. Pada umumnya, hasil akhir untuk pasien skizofrenia wanita adalah lebih baik daripada pasien skizofrenia laki-laki (Sadock, Kaplan, and Grebb, 2010).

Usia rata-rata pasien skizofrenia pada studi ini adalah $35,65 \pm 7,65$. Onset skizofrenia sering terjadi pada masa remaja atau dewasa awal (Sinaga, 2007). Pada studi ini, sebagian besar pasien skizofrenia berpendidikan rendah dan menengah. Bahkan, yang tidak bersekolah cukup besar yaitu $18,33 \%$. Adanya gejala -gejala gangguan skizofrenia terutama gejala negatif dan gangguan kognitif berdampak buruk bagi tingkat pendidikan pasien skizofrenia. Pada studi yang dilakukan Palmer et.al. (1997) didapatkan hanya $27 \%$ pasien skizofrenia yang secara neuropsikologi normal. Hal ini menandakan defisit kognitif pada pasien skizofrenia adalah signifikan. Defisit kognitif berkonstribusi terhadap terjadinya perburukan fungsi. Tidak hanya berpengaruh pada tingkat pendidikan, kesulitan dalam menjaga semangat kerja dan hubungan sosial, hidup mandiri dan mendapatkan ketrampilan dalam program rehabilitasi menyebabkan disabilitas pada pasien skizofrenia (Green et.al. 2006).

Pada studi ini didapatkan pula sebagian besar pasien skizofrenia tidak bekerja, yaitu sebesar $60 \%$. Tidak bekerjanya pasien skizofrenia berkaitan dengan tingkat sosioekonomi. Dalam literatur dijelaskan bahwa sebagian besar pasien skizofrenia berada dalam kelompok sosioekonomi rendah. Hal tersebut dijelaskan oleh hipotesis pergeseran ke bawah (downward drift hypothesis) yang menyatakan bahwa pasien skizofrenia bergeser ke kelompok sosioekonomi yang lebih rendah atau gagal keluar dari kelompok sosioekonomi rendah akibat gangguannya. Suatu penjelasan alternatif adalah hipotesis akibat sosial (social causation hypothesis) yang menyatakan bahwa stres yang dialami oleh anggota kelompok sosioekonomi rendah berperan dalam perkembangan skizofrenia (Kaplan, Sadock \& Grebb, 2010).

Pada studi ini juga didapatkan $76,67 \%$ pasien skizofrenia tidak menikah. Individu yang didiagnosis dengan skizofrenia $60-70 \%$ tidak pernah menikah (Sinaga, 2007). Status menikah pada umumnya merupakan faktor yang mendukung untuk prognosis yang lebih baik pada pasien skizofrenia. Sedangkan sebaliknya pasien skizofrenia yang tidak menikah dikaitkan dengan prognosis yang lebih jelek berkaitan dengan seringnya rawat inap, besarnya tingkat bunuh diri, kualitas hidup yang lebih jelek, tingkat depresi yang lebih banyak dan disabilitas sosial yang lebih berat (Nyer et.al., 2010; Kaplan, Sadock \& Grebb, 2010).

Pada studi ini, berdasarkan penilaian dengan PANNS didapatkan perbedaan yang signifikan dibanding kelompok kontrol dalam perbaikan gejala positif, gejala negatif, psikopatologi umum dan skor total. Hasil ini sesuai dengan hasil studi oleh Levine dan kolega (2006) yang melaporkan terjadinya perbaikan gejala skizofrenia baik gejala positif, gejala negatif maupun skor total. Penelitian tersebut dilakukan pada 42 pasien skizofrenia dengan hiperhomosisteinemia yang dilakukan di Israel dengan 
memberikan terapi tambahan asam folat plus vitamin $\mathrm{B}_{12}$.

Terapi dengan menggunakan asam folat dan vitamin $\mathrm{B}_{12}$ sebenarnya lebih dikaitkan dengan perbaikan gejala negatif. Pada studi RCT (Randomized Contrl Trial) oleh Roffman et.al. (2013) yang dilakukan terhadap 140 pasien skizofrenia dengan diberikan terapi tambahan asam folat $2 \mathrm{mg}$ dan vitamin $\mathrm{B}_{12} 400 \mathrm{mcg}$. Pada studi ini didapatkan perbaikan signifikan pada gejala negatif, sedangkan perubahan gejala positif dan skor total tidak berbeda secara signifikan dengan kelompok terapi yang lain.

Pada studi yang dilakukan penulis, tidak hanya gejala negatif yang mengalami perbaikan, namun pula gejala positif dan psikopatologi umum. Hal ini dipengaruhi oleh antipsikotik yang digunakan oleh subyek. Selama ini, antipsikotik dihubungkan dengan perbaikan yang besar dalam gejala positif dan sedikit perbaikan atau malah memperburuk gejala negatif. Berdasarkan literatur, tingkat respon individu dengan gangguan skizofrenia dalam perbaikan gejala negatif setelah diberikan asam folat dan vitamin $B_{12}$ dipengaruhi oleh variasi genetik sehingga mempengaruhi absorpsi. Gen MTHFR-677C>T dan FOLHI-484T telah dikaitkan dengan perbaikan gejala negatif (Roffman, 2013).

Perbaikan gejala negatif juga dikaitkan dengan meningkatnya kadar asam folat setelah diberikan terapi tambahan asam folat dan vitamin $\mathrm{B}_{12}$. Pada penelitian oleh Donald C. Goff (2004) didapatkan kadar serum folat yang rendah berhubungan signifikan dengan gejala negatif skizofrenia. Mekanisme yang mendasari hal tersebut ada beberapa kemungkinan, seperti rendahnya masukan gizi folat, aktivitas GCPII (Glutamate
Carboksipeptidase II) yang rendah, pengaruh merokok dan keterlibatan folat dalam sintesis neurotransmitter. Studi lanjutan diperlukan untuk mengklarifikasi temuan tersebut (Arrol et.al., 2014).

Dalam literatur lain disebutkan mekanisme folat memperbaiki gejala negatif dan meningkatkan neuroplastisitas tidak jelas, karena folat berperan banyak dalam perkembangan dan fungsi otak. Mekanisme yang diduga terlibat seperti sintesis neurotransmiter, pemeliharaan DNA, modulasi konsentrasi dopamin prefrontal dengan metilasi katekol-Ometil-transferase (COMT), dan modulasi ekspresi gen dan neurogenesis (Goff, 2013).

Terdapat mekanisme yang mencoba menjelaskan peran folat daam memperbaiki gejala negatif yaitu melalui derivatnya, L-metilfolat. MTHFR (metilen tetrahidrofolat reduktase) mengubah folat menjadi L-metilfolat. L-metilfolat beraksi untuk memodulasi sintesis monoamine melalui 3 tahap proses. Yang pertama, Lmetilfolat membatu formasi kofaktor penting yaitu tetrahidro biopterin (BH4). Kedua, BH4 mengaktivasi enzim tirosin hidroksilase dan triptofan hidroksilase. Ketiga, tirosin berikatan dengan tirosin hidroksilase kemudian akhirnya diubah menjadi dopamin dan norepinefrin, sedangkan triptofan berikatan dengan triptofan hidroksilase kemudian akhirnya diubah menjadi serotonin (Stahl, 2008).

Menurut penelitian yang dilakukan oleh Bouaziz et.al. (2010) penurunan kadar homosistein secara signifikan berkaitan dengan keparahan gejala negatif skizofrenia. Song et.al. (2014) dalam penelitiannya mendapatkan korelasi negatif antara homosistein dan kadar asam folat. Dimana kadar homosistein dapat 
diturunkan dengan sumplementasi asam folat dan vitamin $\mathrm{B}_{12}$.

Pada studi yang dilakukan oleh penulis didapatkan tidak ada perbedaan signifikan dalam perbaikan gejala agresi. Hal ini menurut penulis disebabkan subyek yang terlibat dalam studi ini sudah cukup tenang atau kurang agresi sebelum diberikan terapi. Dengan demikian, setelah diberikan antipsikotik dan terapi tambahan folat dan vitamin $B_{12}$ maka perbaikan gejala agresi yang dinilai PANNS hanya sedikit.

\section{KESIMPULAN DAN SARAN}

Asam folat dan kobalamin diberikan sebagai terapi tambahan pada terapi antipsikotik standar pasien skizofrenia. Dari studi yang telah dilakukan dapat diambil simpulan bahwa penambahan asam folat dan kobalamin sebagai adjuvan pada terapi antipsikotik standar efektif dalam memperbaiki gejala negatif dan length of stay pasien skizofrenia kronis. Berdasarkan hasil studi ini diperlukan adanya studi lanjutan dengan desain studi yang mengendalikan faktor-faktor perancu : gaya hidup, status gizi serta faktor genetik dan memperhatikan kadar asam folat dan vitamin $B_{12}$, sehingga mendapat hasil yang lebih baik pada studi penambahan asam folat dan vitamin $B_{12}$ pada pasien skizofrenia.

\section{DAFTAR RUJUKAN}

Ahmad et.al. 2011. Folate and vitamin $B_{12}$ status in schizophrenic patients. Department of Nutrition and Biochemistry, School of Public Health, Tehran University of Medical Sciences, Tehran, Iran.

Anderson SW, et.al. 2004. Predicting inpatient length of stay with the expanded version of the brief psychiatric rating scale. Psychiatric Serv; 55: 77-9.

Arrol, M.A.; Wilder, R \& Neil, J. 2014. Nutritional Interventions for The Adjunctive Treatment of Schizophrenia: A Brief Review. Nutrition Journal 2014, 13:91

Biancospino B, et.al. 2004. The BPRS-E as predictor of length of stay in a residential facility. Psychiatric Serv; 55(1): 77-9.

Bouaziz N, et.al. 2010. Plasma homocysteine in schizophrenia: Determinants and clinical correlations in Tunisian patients free from antipsychotics. Psychiatry Research 179 (2010) 24-29. doi:10.1016/j.psychres.2010.04.00 8.

Bottiglieri T, 2009. Homocysteine and folate metabolism in depression. ProgNeuro-Psychopharmacol Biol Psychiatry; 29: 1103-12.

Colasanti A., et.al. 2010. Hospitalization, and Aggressive Behaviours in Acutely Hospitalized Patients with Psychotic Exacerbation. Clinical Practice \& Epidemiology in Mental Health, 2010, 6, 72-78.

Depkes RI. 2014. Riset Kesehatan Dasar (RISKESDAS) 2013. Jakarta : Departemen Kesehatan RI.

García-Miss et.al. 2010. Folate, homocysteine, interleukin-6, and tumor necrosis factor alfa levels, but not the methylenetetrahydrofolate reductase C677T polymorphism, are risk factors for schizophrenia. Journal of Psychiatric Research 44 (2010) 441-446. 
Goff et al., 2004. Folate, homocysteine, and negative symptoms in schizophrenia. Food and Behaviour Research No SC034604.

Goff, D.C. 2013. Future Perspectives on The Treatment of Cognitive Deficits and Negative Symptoms in Schizophrenia. World Psychiatry 2013;12:99-107.

Green, M.F. 2006. Cognitive Impairment and Functional Outcome in Schizophrenia and Bipolar Disorder. J Clin Psychiatry; 67 (suppl 9) : 3-8.

Levine SZ, et.al., 2006. HomocysteineReducing Strategies Improve Symptoms in Chronic Schizophrenic Patients with Hyperhomocysteinemia. BIOL PSYCHIATRY 2006;60:265-269

Miyamoto et.al. 2005. Treatments for schizophrenia: a critical review of pharmacology and mechanisms of action of antipsychotic drugs. Mol Psychiatry. 2005;10(1):79-104.

Nyer, M; Kasckow, J; Fellow, I; et.al. 2010. The relationship of marital status and clinical characteristics in middle-aged and older patients with schizophrenia and depressive symptoms. Annals of Clinical Psychiatry. 2010;22(3):172-179.

O'Leary et.al. 2011. Vitamin status, dietary intake and length of stay in a sample of elderly rehabilitation patients. J Nutr Health Aging. 15:485-9.

Oshima I., Mino Y., dan Inomata Y. 2003. Institutionalisation and schizophrenia in Japan: social environments and negative symptoms Nationwide survey of in- patients. British Journal Of Psychiatry, 183,5 0-5 6.

Patel et.al. 2014. Investigation of negative symptoms in schizophrenia with a machine learning text-mining approach. www.thelancet.com

Patel et.al. 2015. Negative symptoms in schizophrenia: a study in a large clinical sample of patients using a novel automated method. BMJ Open 2015;5:e007619. doi:10.1136/bmjopen-2015007619

Roffman JL, et.al., 2013. A Randomized Multi-Center Investigation of Folate Plus $B_{12}$ Supplementation in Schizophrenia. JAMA Psychiatry; 70(5): $\quad$ 481-489. doi:10.1001/jamapsychiatry.2013. 900.

Sadock BJ, Kaplan HI, Grebb JA. 2010. Sinopsis Psikiatri Ilmu Pengetahuan Prilaku Psikiatri Klinis Jilid 1. Jakarta: Binarupa Aksara.

Sarah et.al., 2011. Cerebral folate deficiency: A neurometabolic syndrome? Elsevier Molecular Genetics and Metabolism 104 (2011) 369-372.

Sinaga BR. 2007. Skizofrenia dan Diagnosis banding, Jakarta :12-137

Stahl, S.M. 2008. L- Methylfolate : $A$ Vitamin for Your Monoamine. J. Clin Psychiatry 69:9 September 2008.

Wang D, et.al. 2016. Serum folate levels in schizophrenia: A meta-analysis. Elsevier Psychiatry Research 23583-89. 